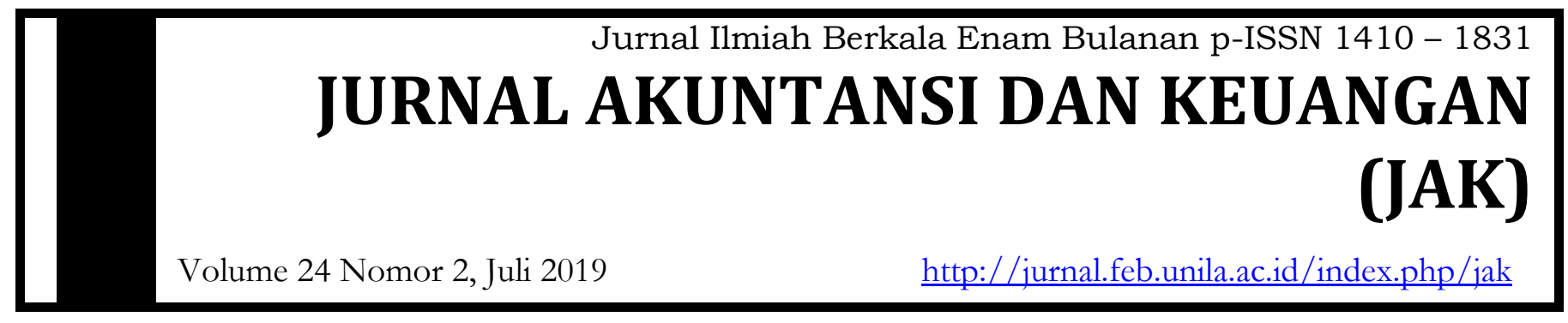

\title{
PENGARUH PEMBIAYAAN MURABAHAH DAN SUKU BUNGA BI TERHADAP PENDAPATAN MARGIN MURABAHAH PERBANKAN SYARIAH (STUDI PADA BUS DI INDONESIA)
}

\author{
Sindy Silvya Rosa', Mia Kusumawaty ${ }^{2}$ \\ ${ }^{1}$ Universitas Muhammadiyah Palembang \\ ${ }^{2}$ Universitas Muhammadiyah Palembang
}

\section{Informasi Naskah}

\section{Update Naskah:}

Dikumpulkan: 30 Mei 2019

Diterima: 30 Juni 2019

Terbit/Dicetak: 30 Juli 2019

\section{Keywords:}

Maksimum5 kata kunci dipisahkan dengan tanda koma.

[Font Cambria 11 spasi tunggal, dan cetak miring]

\section{Abstract}

The research objective was to determine the effect of murabaha financing and interest rate BI to Revenue Margin On Islamic Banking simultaneously and partially. This type of research is associative research. The data digunakanadalah secondary data, where the data is murabaha financing resources and Bank Indonesia interest rate and margin murabaha year 2011-2015 at six banks listed in Indonesia. Data collection techniques in this study is documentation. Data analysis techniques used in this research is qualitative analysis techniques. The analytical method used in this research is multiple linear regression analysis.

The results of this study showed that simultaneous Murabahah Financing and Interest Rates Bank Indonesia influence Revenue Margin Murabaha Islamic Banking in Indonesia. Partially Financing Murabahahm significant effect on Income Margin Murabaha Islamic Banking in Indonesia, while the interest rate of Bank Indonesia partially no significant effect on Income Margin Murabaha Islamic Banking in Indonesia 


\section{A. PENDAHULUAN}

Bank merupakan salah satu lembaga keuangan yang mempunyai peranan penting di dalam perekonomian suatu negara sebagai lebaga perantara keuangan. Bank dalam Pasal 1 ayat (2) UU No. 10 Tahun 1998 tentang perubahan UU No. 7 Tahun 1992 tentang perbankan adalah badan usaha yang menghimpun dana dari masyarakat dalam bentuk kredit dan atau bentuk - bentuk lain dalam rangka meningkatkan taraf hidup rakyat banyak. Jenis bank di Indonesia dibedakan menjadi dua jenis bank, yang dibedakan berdasarkan pembayaran bunga atau bagi hasil usaha: pertama, Bank yang melakukan usaha secara konvensional, dan kedua, Bank yang melakukan usaha secara syariah.

Bank syariah yang berfungsi sebagi lembaga intermendiasi keuangan, melaksanakan kegiatan operasionalnya dengan menghimpun dana dari masyarakat dan kemudian menyalurkannya kembali kepada masyarakat biasanya disimpan dalam bentuk giro, tabungan dan deposito baik dengan prinsip wadiah maupun prinsip bagi hasil. Sedangkan penyaluran dana dilakukan oleh bank syariah melalui pembiayaan empat pola penyaluran yaitu bagi hasil, jual beli, prinsip ujroh dan akad pelengkap.

Jasa pembiayaan yang ditawarkan oleh bank syariah secara alamiah merujuk pada dua katagori kegiatan ekonomi yaitu produksi dan distribusi. Pada kategori produksi difasilitasi melalui skema bagi hasil yaitu mudhrabahdan musyarakah, sedangkan kegiatan distribusi difasilitasi melalui skema jual beli yaitu murabahah. Meskipun banyak prinsip penyaluran dana yang dipakai oleh bank syariah namun, jual beli akad murabahah yang sering digunakan. Karena, produk murabahah ini sangat sering ditawarkan oleh bank syariah sehingga sangat dikenal dikalangan masyarakat luas. Menurut Wiroso (2011: 73), murabahah adalah jual beli barang pada harga asal dengan tambahan keuntungan yang disepakati. Dalam jual beli murabahah, penjual harus memberi tahu produk yang dia beli dan menentukan suatu tingkat keuntungan sebagai tambahannya. Dalam penentuan keuntungan ditentukan sesuai dengan kesepakatan antara pihak bank dengan pihak nasabah. Mengenai pengambilan keuntungan, menurut pendapat Adi Warman A.Karim (2011: 254) terdapat beberapa pertimbangan yang telah ditetapkan dalam rapat ALCO (Asset-Liability Commite) bank syariah. Yakni, Direct Competitor's Market Rate (DCMR)

Akad murabahah merupakan akad jual beli barang pada harga pokok dengan tambahan keuntungan yang disepakati, akibat transaksi jual beli murabahah menyebabkan timbulnya piutang murabahah. Karena adanya penangguhan pembayaran ini menimbulkan kesan bahwa pembiayaan murabahah tidak berbeda dengan pemberian kredit berbunga oleh bank konvensional. Di dalam debt financing (pembiayaan hutang) bank konvensional ada beberapa unsur seperti adanya pre fixed interst (bunga) yang ditetapkan di awal peminjaman, bunga tersebut muncul akibat dari penundaan pembayaran dan wujudnya spekulasi. Kalau dalam konvensional ada pre-fixed interest, maka di dalam murabahah ada pre-fixed profit (suatu penentapan tambahan), dan penambahan itu juga disebabkan karena adanya unsur penundaan pembayaran. Unsur spekulasi terhadap perubahan base landing rate (suku bunga) telah dihilangkan dengan memakai fixed rate (nilai mark up yang tetap). Selain dari besarnya pembiayaan murabahah, besarnya pendapatan yang diperoleh dari pembiayaan murabahah akan sangat berkaitan dengan besarnya tingkat margin murabahah yang dibebankan bank syariah kepada nasabah pembiayaan. Bank syariah dalam memperhitungkan keuntungan murabahah menggunakan pendekatan base lending rate, hal tersebut dikarenakan belum adanya rumusan baku mengenai perhitungan keuntungan murabahah.

Berdasarkan fenomena mengenai penetapan tingkat margin murabahah, bahwa bank syariah menggunakan pendekatan base lending rate bank konvensional sebagai perhitungan keuntungan murabahah. Sehingga, unsur-unsur yang terkandung dalam base lending rate yang diungkap oleh wiroso $(2005,92)$ yaitu ekspektasi bagi hasil, biaya overhead, keuntungan dan premi resiko. Sedangkan menurut perwataatmadja (dalam nugroho, 2005) cost recovery (proyeksi biaya operasi dibagi target volume pembiayaan murabahah) dan keuntungan yang diinginkanlah yang akan mempengaruhi besarnya margin murabahah. Tujuan dalam penelitian adalah Untuk mengetahui Pengaruh Pembiayaan Murabahah dan Suku Bunga BI Terhadap Jumlah Margin Murabahah pada Perbankan Syariah secara Simultan dan Parsial. 


\section{B. LANDASAN TEORI DAN PENGEMBANGAN HIPOTESIS}

\section{Perbankan Syariah}

Berdasarkan Undang-undang Republik Indonesia No. 21 Tahun 2008 tentang perbankan syariah, definisi bank syariah adalah "bank yang menjalankan kegiatan usahanya berdasarkan prinsip syariah".

Fungsi dari bank syariah sesuai dengan Undang-undang No. 21 Tahun 2008 adalah fungsi sosial dalam bentuk lembaga baitul mal, fungsi jasa keuangan perbankan dengan menghimpun dana menyalurkan dana masyarakat sesuai dengan prinsip-prinsip syariah, fungsi sebagai manajer investasi atas dana yang dihimpun dari pemilik dana, serta fungsi sebagai investor dalam penyaluran dana baik dalam prinsip bagi hasil, prinsip ujroh, maupun prinsip jual beli.

Undang-undang No. 21 Tahun 2008 dalam pasal 3 disebutkan tujuan bank syariah adalah "menunjang pelaksanaan pembangunan nasional dalam rangka meningkatkan keadilan, kebersamaan, dan pemerataan kesejahteraan rakyat.

\section{Pembiayaan Murabahah}

Bai' al-Murabahah adalah jual beli barang pada harga asal dengan tambahan keuntungan yang disepakati. Dalam bai' al-murabahah, penjual harus memberi tahu harga produk yang ia beli dan menentukan suatu tingkat keuntungan sebagai tambahannya (Syafi'i, 2005: 101). Definisi lain murabahah adalah akad jual beli barang dengan menyatakan harga perolehan dan keuntunagn (margin) yang disepakati oleh penjual (Karim, 2008: 113).

Muslim harus mengetahui jual beli yang diperbolehkan dalam syariah, agar harta yang dimiliki halal dan baik, seperti kita mengetahui jual beli adalah salah satu aspek dalam muamalah (hubungan manusia dengan manusia), dengan kaidah dasar semua boleh kecuali yang dilarang.

Pertukaran uang dengan barang yang biasa dikenal dengan jual beli dapat dilakukan secara tunai atau dengan cara pembelian tangguh. Pertukaran barang dengan barang, terlebih dahulu harus memperhatikan apakah barang tersebut merupakan barang ribawi (secara kasat mata tidak dapat dibedakan) atau bukan. Untuk pertukaran barang ribawi seperti emas dangan emas, perak dengan perak, gendum dengan gendum, tepung dengan tepung, kurma dengan kurma, anggur kering denga anggur kering dan garam dengan garam maka pertukarannya agar sesuai syariah harus dengan jumlah yang sama dan harus dari tangan ke tangan atau tunai, karena kelebihannya adalah riba(Sri dan wasilah, 2012: 168).

\section{Tingkat Suku Bunga}

Suku Bunga adalah harga dari penggunaan uang atau bias juga dipandang sebagai sewa atas penggunaan uang untuk jangka waktu tertentu. Atau harga dari meminjam uang untuk menggunakan daya belinya dan biasanya dinyatakan dalam persen (\%).

Bunga bank dapat diartikan sebagai balas jasa yang diberikan oleh bank yang berdasarkan prinsip Konvensional kepada nasabah yang membeli atau menjual produknya. Bunga juga dapat diartikan sebagai harga yang harus dibayar kepada nasabah (yang memiliki simpanan) dengan yang harus dibayar oleh nasabah kepada bank (nasabah yang memperoleh pinjaman). (Kasmir, 2010: 133).

\section{Suku bunga Bank Indonesia}

BI Rate atau suku bunga Bank Indonesia adalah suku bunga kebijakan yang mencerminkan sikap atau stance kebijakan moneter yang ditetapkan oleh Bank Indonesia dan diumumkan kepada publik. BI Rate diumumkan oleh Dewan Gubernur Bank Indonesia setiap Rapat Dewan Gubernur bulanan dan diimplementasikan pada operasi moneter yang dilakukan Bank Indonesia melalui pengelolaan likuiditas (liquidity management) di pasar uang untuk mencapai sasaran operasional kebijakan moneter.

Sasaran operasional kebijakan moneter dicerminkan pada perkembangan suku bunga Pasar Uang Antar Bank Overnight (PUABO/N). Pergerakan di suku bunga deposito, dan pada gilirannya suku bunga kredit perbankan. 


\section{Margin Murabahah}

Pengertian tingkat margin menurut Keputusan Menteri Negara Koperasi Dan Usaha Kecil Menengah tentang Petunjuk Kegiatan Usaha Koperasi Jasa Keuangan Syariah, "Margin adalah keuntungan yang diperoleh koperasi atas hasil transaksi penjualan dengan pihak pembelinya".

Penjelasan lain tentang margin dalam menentukan jangka waktu pembiayaan adalah persentase tertentu yang ditentapkan per tahun, perhitungan margin keuntungan secara harian, maka jumlah hari dalam setahun ditetapkan 360 hari, perhitungan margin secara bulanan maka ditetapkan 12 bulan. Pada umumnya, nasabah melakukan pembayaran secara angsuran (Adiwarman, 2011 :280). Menurut PSAK NO.23 pendapatan adalah sebagai berikut: "Arus masuk bruto dari manfaat ekonomi yang timbul dari aktivitas normal perusahaan selama satu periode bila arus masuk itu mengakibatkan kenaikan ekuitas yang tidak berasal dari kontribusi penanaman modal".

Menurut solihin (2010: 492) margin keuntungan/ mark up merupakan: "Persentase tertentu yang ditetapkan pertahun: jadi jika perhitungan margin keuntungan secara harian, jumlah hari dalam setahun ditetapkan 360 hari dan jika perhitungan margin keuntungan secara bulanan setahun ditetapkan 12 bulan. Pada umumnya, nasabah pembiayaan melakukan pembiayaan secara angsuran. Tagihan yang timbul dari transaksi murabahah, salam istisna dan ijarah disebut sebagai piutang. Besaran piutang tersebut tergantung pada plafond pembiayaan yakni jumlah pembiayaan (harga beli ditambah harga pokok) yang tercantum didalam perjanjian pembiayaan”.

Jadi pendapatan margin murabahah adalah penerimaan dana (Arus Masuk Bruto) baik tunai maupun bukan tunai yang merupakan hasil dari perhitungan persentase keuntungan yang timbul dari transaksi murabahah yang besarnya telah ditentukan pada awal akad sesuai dengan kesepakatan yang tercantum didalam perjanjian pembiayaan

\section{Hipotesis Penelitian}

Faktor-fakotr yang mempengaruhi besarnya mark-up adalah kebutuhan syariah untuk memperoleh keuntungan riil, inflasi, suku bunga berjalan, kebijakan moneter, dan maretabilitas barang-barang murabahah serta tingkat laba yang diharapkan dari barang-barang itu.

Murabahah merupakan kegiatan terpenting dari jual beli dan prinsip akad ini mendominasikan pedapatan bank dari produk-produk yang disemua bank islam. Atas penerimaan angsuran murabahah yang dilakukan secara tunai, maka terdapat aliran kas masuk atas pendapatan margin sehingga pendapatan margin murabahah tersebut merupakan unsur pendapatan operasional.

Berdasarkan penjelasan diatas dapat disimpulkan bahwa hipotesis dari penelitian ini adalah:Pembiayaan Murabahah Dan Tingkat Suku Bunga Bank Indonesia Berpengaruh Secara Simultan Terhadap Pendapatan Margin Murabahah.

\section{METODE PENELITIAN}

\section{Jenis Penelitian}

Jenis penelitian yang akan digunakan dalam penelitian ini adalah penelitian asosiatif, yaitu penelitian yang dilakukan bertujuan untuk mengetahui hubungan antara variabel independen pembiayaan murabahah dan suku bunga Bank Indonesia terhadap Pendapatan Margin Murabahah.

\section{Lokasi Penelitian}

Penelitian ini dilakukan pada 6 Perbankan Syariah yan terdaftar di Indonesia (Online) diakses melalui http://www.bi.go.id/id/publikasi/laporan-keuangan/bank/umum-syariah/Default.aspx.

\section{Operasionalisasi Variabel}

\section{Murabahah $\left(\mathbf{X}_{1}\right)$}

Bai' al-Murabahah adalah jual beli barang pada harga asal dengan tambahan keuntungan yang disepakati. Dalam bai' al-murabahah, penjual harus memberi tahu harga produk yang ia beli dan menentukan suatu tingkat keuntungan sebagai tambahannya (Syafi'i, 2005: 101). Indikator digunakan 
Pembiayaan margin yang sudah ditetapkan.

\section{Suku Bunga Bank Indonesia $\left(\mathbf{X}_{2}\right)$}

Suku bunga bank indonesia adalah suku bunga kebijakan yang mencerminkan sikap atau stace kebijakan moneter yang ditetapkan oleh bank indonesia dan diumumkan kepada publik. Indikator yang digunakan adalah Inflasi.

\section{Pendapatan Margin Murabahah (Y)}

Pendapatan margin murabahah yaitu selisih antara harga beli dan harga jual yang merupakan keuntungan kotor dalam transaksi jual beli barang, margin tidak sama dengan bunga karena margin sudah ditentukan pada awal perjanjian dan tidak dapat berubah ditengah jalan. Indikator yang digunakan adalah Persentasi dari harga pokok.

\section{Data yang Diperlukan}

Data yang akan digunakan dalam penelitian ini adalah data sekunder yaitu dimana data yang didapatkan secara tidak langsung dapat dijadikan sumber informasi data pembiayaan murabahah dan Suku Bunga Bank Indonesia tahun 2011-2015, serta Pendapatan Margin Murabahah tahun 2011-2015 Pada 6 Bank Syariah yang terdaftar di Indonesia.

\section{Metode Pengumpulan Data}

Teknik pengumpulan data yang akan digunakan dalam penelitian ini adalah dokumentasi dilakukan dengan menyalin maupun mengutip dokumen pada 6 Bank Syariah yang terdaftar di Indonesia yang berhubungan dengan masalah yang akan diteliti sehingga sesuai dengan penelitian.

\section{Analisis Data dan Teknik Analisis}

\section{Analisis Data}

Metode analisis data yang akan digunakan dalam penelitian ini adalah analisis kuantitatif.

Analisis kuantitatif digunakan dengan menggunakan rumus-rumus statistik yang sesuai dengan penelitian untuk menilai hasil data tersebut diuji melalui pengujian statistik yang dibantu oleh aplikasi progam Statistical Product and Service Solution/SPSS.

\section{Teknik Analisis}

Teknik analisi data yang akan digunakan untuk mengetahui pengaruh pembiayaan murabahah dan suku bunga Bank Indonesia terhadap pendapatan margin murabahah adalah dengan menggunakan analisis regresi linier berganda untuk meyakinkan bahwa variabel bebas mempunyai pengaruh terhadap variabel terikat.

$$
\mathrm{Y}=\mathrm{a}+\mathrm{b}_{1} \mathrm{X}_{1}+\mathrm{b}_{2} \mathrm{X}_{2}+\mathrm{e}
$$

Keterangan :

$$
\begin{aligned}
& \mathrm{Y}=\text { Profitabilitas } \\
& \text { A } \quad=\text { Konstanta (nilai Y bila } \mathrm{X}=0 \text { ) } \\
& \mathrm{b}_{1} \mathrm{~b}_{2} \quad=\text { Koefisien regresi } \\
& \mathrm{X}_{1} \quad=\text { Murabahah } \\
& \mathrm{X}_{2} \quad=\text { Musyarakah } \\
& \text { e } \quad=\text { error }
\end{aligned}
$$

(Sugiyono, 2014: 277).

\section{ANALISIS DAN PEMBAHASAN}

\section{Hasil Penelitian}

\section{Deskripsi Data dan Analisis}

Bank yang diambil sudah terdaftar dan diakui oleh Bank Indonesia sebagai Bank Syariah, terdapat 
12 Bank Syariah yang ada di Indonesia, akan tetapi yang memenuhi kriteria untuk diteliti hanya sebanyak 6 Bank. Jumlah data yang dipakai sebanyak 30 (6x5) untuk periode Tahun 2011 sampai 2015. Penelitian menggunakan 3 variabel yaitu Pembiayaan Murabahah, Suku Bunga Bank Indonesai dan Pendapatan Margin Murabahah.

Unsur yang digunakan untuk mengetahui terdapatnya pengaruh pembiayaan murabahah dan suku bunga Bank Indonesia terhadap pendapatan margin murabahah maka penulis melakukan pengolahan data dibantu oleh (Statistical Product and Service Solution/SPSS).

\section{Analisis Regresi Linier Berganda}

\section{Coefficients $^{\mathrm{a}}$}

\begin{tabular}{|c|c|c|c|c|c|c|}
\hline & \multirow{2}{*}{ Model } & \multicolumn{2}{|c|}{ Unstandardized Coefficients } & \multirow{2}{*}{$\begin{array}{c}\text { Standardized Coefficients } \\
\text { Beta }\end{array}$} & \multirow{2}{*}{$\mathbf{t}$} & \multirow{2}{*}{ Sig. } \\
\hline & & B & Std. Error & & & \\
\hline \multirow[t]{3}{*}{1} & (Constant) & 373.136 & 567.094 & & .658 & .516 \\
\hline & Murabahah & .077 & .005 & .955 & 15.586 & .000 \\
\hline & Suku Bunga & -25.827 & 83.487 & -.019 & -309 & -759 \\
\hline
\end{tabular}

a. Dependent Variable: Margin

Sumber: Data Hasil SPSS diolah Tahun 2017

Berdasarkan tabel diatas hasil uji regrisi linier berganda, diperoleh persamaan regresi linier berganda sebagai berikut:

$$
\begin{aligned}
& Y=a+b_{1} x_{1}+b_{2} x_{2}+\varepsilon \\
& Y=373,136+0,077 X_{1}-25,827 X_{2}+\varepsilon
\end{aligned}
$$

Hasil ini menunjukan jika nilai variabel Murabahah $\left(\mathrm{X}_{1}\right)$ dan Suku Bunga Bank Indonesia $\left(\mathrm{X}_{2}\right)$ nilainya adalah 0, maka Pendapatan Margin Murabahah nilainya adalah 373,136. Sedangkan jika variabel Murabahah dinaikan 100\% (dengan asumsi bahwa nilai koevisien variabel lain konstan atau tidak berubah), maka akan mengakibatkan adanya peningkatan Pendapatan Margin Murabahah sebesar 0,077, koefisien bernilai positif, dan jika variabel Suku Bunga Bank Indonesia dinaikan 100\% (dengan asumsi bahwa nilai koevisien variabel lain konstan atau tidak berubah), maka akan mengakibatkan adanya penurunan Pendapatan Margin Murabahah sebesar -25,827, koefisien bernilai negatif.

\section{Uji Model}

Semakin melakukan analisis data maka data diuji sesuai asumsi klasik yang bertujuan untuk mendapatkan regresi yang baik yang terdistribusi dengan normalitas, terbatas dari multikolinieritas, terbebas dari heteroskedasitas dan terbatas dari autokorelasi.

\section{Uji Normalitas}

dapat disimpulkan bahwa grafik Normal $P$-P plot terlihat titik-titik menyebar di sekitar garis diagonal dan penyebrannya mengikuti arah garis diagonal, maka grafik menunjukan bahwa model regresi layak dipakai karena memenuhi asumsi normalitas.

\section{Uji Multikolinieritas}

Untuk mendeteksi ada atau tidaknya multikolinearitas di dalam model penelitian ini yaitu sebagai berikut:

1. Nilai Tolerance

2. Tidak terjadi multikolonearitas, jika nilai tolerance $>0,10$.

3. Terjadi Multikolinearitas, jika nilai tolerance $<0,10$.

4. Nilai VIF (Variance Inflation Factor)

1. Tidak Terjadi Multikonieritas, jika nilai VIF $<10,00$

2. Terjadi Multikonieritas, jika nilai VIF $>10,00$ 
Berdasarkan Output SPSS di atas, dapat disimpulkan bahwa tidak terjadi multikolinearitas antar variabel independent dalam model regresi karena nilai tolerance $>0.1$ dan nilai VIF $<10$.

\section{Uji Heteroskedastisitas}

antara nilai prediksi variabel dependen dengan residualnya deperoleh hasil tidak adanya pola yang jelas dan titik-titik menyebar di atas dan dibawah angka 0 pada sumbu Y, maka tidak terjadi heteroskedasitas.

\section{Uji Autokorelasi}

hasil uji autokorelasi diperoleh nilai Durbin Watson (DW) 1,447. Karena nilai DW berkisar antara 2 dan +2 , hal ini menunjukan bahwa dalam persamaan regresi pada penelitian ini tidak terjadi autokorelasi.

\section{Uji Hipotesis}

\section{Hasil Uji Secara Simultan (Uji F)}

\begin{tabular}{llccccc}
\hline \multicolumn{1}{c}{ Model } & Sum of Squares & Df & Mean Square & F & Sig. \\
\hline 1 Regression & $3.600 \mathrm{E} 7$ & 2 & $1.800 \mathrm{E} 7$ & 127.326 & $.000^{\mathrm{a}}$ \\
Residual & 3816671.258 & 27 & 141358.195 & & \\
Total & $3.981 \mathrm{E} 7$ & 29 & & & \\
\hline \hline
\end{tabular}

a. Predictors: (Constant), Suku Bunga , Murabahah

b. Dependent Variable: Margin Murabahah

\section{Sumber: Data Hasil SPSS diolah Tahun 2017}

Dari hasil analisis di atas Uji Anova $F$ test diperoleh $F_{\text {hitung }}$ sebesar 127,326 sedangkan $F_{\text {tabel }}$ dengan tingkat signifikan 0,05 diperoleh $F_{\text {tabel }}$ sebesar 3,354. nilai $\mathbf{F}_{\text {hitung }}>$ nilia $\mathbf{F}_{\text {tabel }}(\mathbf{1 2 7 , 3 2 6}>\mathbf{3 , 3 5 4})$, Hasil uji F juga diketahui bahwa nilai signifikan yang muncul adalah sebesar 0,0000 . Berdasarkan kriteria pengujian, karena nilai sig $\mathbf{F}<\mathbf{0 , 0 5}(\mathbf{0 , 0 0 0 0}<\mathbf{0 , 0 5})$ berarti terdapat pengaruh yang signifikan. Maka kesimpulannya pembiayaan Murabahah dan Suku Bunga Bank Indonesia berpengaruh signifikan terhadap Margin Murabahah Perbankan Syariah.

\section{Uji Secara parsial (t)}

\section{Hasil Uji Secara Parsial}

\section{Coefficients $^{\mathrm{a}}$}

\begin{tabular}{llcc}
\hline & Model & t & Sig. \\
\hline \hline 1 & (Constant) & .658 & .516 \\
& Murabahah & 15.586 & .000 \\
& Suku Bunga & -.309 & .759 \\
\hline \hline
\end{tabular}

a. Dependent Variable: Margin Murabahah

Sumber: Pengolahan Data SPPS Tahun 2017

Ha diterima apabila $\mathrm{t}_{\text {hitung }}<\mathrm{t}$ tabel

Ho ditolak apabila $t_{\text {hitung }}>t_{\text {tabel }}$

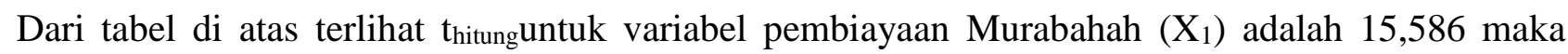
hasilnya $\mathrm{t}$ hitung $>\mathrm{t}$ tabel $=15,596>2,048$ sehingga Ho ditolak sehingga berpengaruh signifikan. Maka kesimpulannya secara persial pembiayan Murabahah berpengaruh signifikan terhadap Margin Murabahah.

Sedangkan untuk nilai thitung variabel Suku Bunga Bank Indonesia $\left(\mathrm{X}_{2}\right)$ adalah -0,309 maka hasilnya $\mathrm{t}$ hitung $<\mathrm{t}$ tabel $=-0,309<2,048$ sehingga Ho diterima. Maka kesimpulannya bahwa Suku Bunga Bank Indonesia tidak berpengaruh secara parsial terhadap Margin Murabahah. 


\section{Uji Koefisien Determinasi}

\section{Hasil Koefisien Determinasi}

Model Summary

\begin{tabular}{cccccc}
\hline Model & R & R Square & Adjusted R Square & Estimate & Durbin-Watson \\
\hline \hline 1 & $.951^{\mathrm{a}}$ & .904 & .897 & 375.976 & 1.447 \\
\hline \hline
\end{tabular}

a. Predictors: (Constant), Suku Bunga, Murabahah

b. Dependent Variable: Margin Murabahah

\section{Sumber: Pengolahan Data SPPS Tahun 2017}

Besarnya angka Adjusted $R$ Square atau nilai koefisien determinasi adalah 0,897. Artinya bahwa variabel Pendapatan Margin Murabahah dapat dijelaskan oleh variabel pembiayaan Murabahah dan suku bunga bank Indonesiasebesar $89,7 \%$ atau besarnya pengaruh pembiayaan murabahah dan suku bunga bank Indonesia terhadap pendapatan margin murabahah adalah sebesar $89,7 \%$. Sedangkan sisanya $(100 \%-$ $89,7 \%=10,3 \%$ ) dipengaruhi oleh variabel lain yang tidak diikutsertakan dalam penelitian ini, seperti faktor Bagi Hasil Dana Pihak Ktiga, Biaya Oprasional, dan Faktor lainny.Nilai Adjusted $R$ Square berkisar antara 0 sampai 1, catatan semakin kecil nilai Adjusted $R$ Square, maka semakin lemah hubungan antara variabelvariabel tersebut.

\section{Pembahasan}

\section{Pengaruh Pembiayaan Murabahah dan Suku Bunga Bank Indonesia Terhadap Pendapatan Margin Murabahah Perbankan Syariah}

Berdasarkan hasil penelitian, total tingkat penyaluran pembiayaan murabahah dan suku bunga bank Indonesia Perbankan Syariah dari tahun 2011 sampai dengan tahun 2015 terus mengalami peningkatan, dan hasil penelitian yang dilakukan dalam penelitian ini menunjukan bahwa pembiayaan Murabahah dan Suku Bunga Bank Indonesia berpengaruh signifikan terhadap Pendapatan Margin Murabahah Perbankan Syariah.

Hasil ini dibuktikan nilai $F_{\text {hitung }}>$ nilia $F_{\text {tabel }}(\mathbf{1 2 7 , 3 2 6}>3,354)$ dan nilai sig $\mathbf{F}<\mathbf{0 , 0 5}(\mathbf{0 , 0 0 0 0}<0,05)$. Hal ini berarti bahwa besarnya laba atau profit tentu berhubungan dengan besarnya pembiayaan yang disalurkan serta keberhasilan bank syariah dalam melakukan kegiatan usahanya.

\section{Pengaruh Pembiayaan Murabahah Terhadap Pendapatan Margin Murabahah Perbankan Syariah}

Pada tahun 2011 sampai dengan tahun 2015 tingkat pembiayaan murabahah pada Perbankan Syariah setiap tahunnya mengalami peningkatan dan penurunan, dan pada pendapatan Margin Murabahah juga mengalami peningkatan dan penurunan secara drastis. Kecenderungan penurunan pembiayaan Murabahah disebabkan nasabah yang mengajukan pembiayaan murabahah setiap tahunnya berkurang dikarnakan nasabah lebih memilih pembiayaan lain dibandingkan pembiayaan murabahah dan juga nasabah memilih perpindah bank lain.

Hasil yang diperoleh dari uji regresi linier berganda nilai koefisien variabel Murabahah $\left(\mathrm{X}_{1}\right)$ sebesar 0,077, artinya jika variabel Murabahah dinaikan 100\% maka mengakibatkan adanya peningkatan pendapatan Margin Murabahahsebesar 0,077. Koefisien bernilai positif artinya terjadi hubungan positif antara variabel Murabahah $\left(\mathrm{X}_{1}\right)$ dengan Pendapatan Margin Murabahah (Y). Semakin tinggi pembiayaan murabahah maka semakin meningkat pendapatan Margin Murabahah Perbankan Syariah.

Berdasarkan tingkat signifikan nilai thitung 15,596> nilai ttabel 2,048 dengan kreteria pengujian nilai

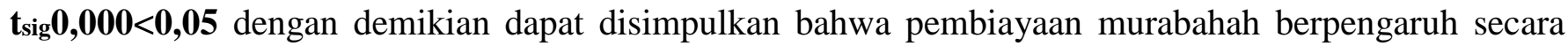
signifikan terhadap pendapatan Margin Murabahah Perbankan Syariah. Pembiayaan Murabahah berpengaruh positif dikarenakan penerimaan angsuran pendapatan margin yang dilakukan secara tunai. 


\section{Pengaruh Suku Bunga Bank Indonesia Terhadap Pendapatan Margin Murabahah Perbankan Syariah}

Pada tahun 2011 samapai dengan tahun 2015, suku bunga Bank Indonesia mengalami fluktuasi atau peningkatan dan penurunan, sedangkan pendapatan Margin Murabahah Perbankan Syariah mengalami peningkatan dan penurunan secara drastis. Peningkatan dan penurunan suku bunga Bank Indonesa tergantung inflansi dan keputusan Dewan Gubernur Bank Indonesia bulanan dan diimplementasikan pada operasi moneter yang dilakukan Bank Indonesia melalui pengelolaan likuiditas dipasar uang untuk mencapai sasaran oprasional kebijakan moneter.

Hasil yang diperoleh dari uji regresi linier berganda nilai koefisien variabel Musyarakah $\left(\mathrm{X}_{2}\right)$ sebesar -25,827, artinya jika variabel suku bunga Bank Indonesia dinaikan 100\% maka mengakibatkan adanya penurunan Pendapatan Margin Murabahah sebesar -25,827. Koefisien bernilai negatif artinya terjadi hubungan negatif antara variabel suku bunga Bank Indonesia $\left(\mathrm{X}_{2}\right)$ dengan Pendpatan Margin Murabahah Perbankan Syariah.

Berdasarkan tingkat signifikan nilai $\mathbf{t}_{\text {hitung }} \mathbf{- 0 , 3 0 9}<$ nilai $\mathbf{t}_{\text {tabel }} \mathbf{2 , 0 4 8}$ dengan kriteria pengujian nilai $\mathbf{t}_{\text {sig }}$ 0,759 > 0,05. Dengan demikian dapat disimpulkan bahwa suku bunga Bank Indonesia tidak berpengaruh secara signifikan terhadap Pendapatan Margin Murabahah Perbankan Syariah. Suku bunga Bank Indonesia berpengaruh negatif dikarenakan lebih tingginya suku bunga Bank Indonesia dari pada Pendapatan Margin Murabahah pada Perbankan Syariah.

\section{E. SIMPULAN DAN SARAN}

\section{Simpulan}

1. Pembiayaan Murabahah secara parsial berpengaruh signifikan terhadap Pendapatan Margin Murabahah Perbankan Syariah di Indonesia. Hal ini ditunjukkan dari nilai thitung lebih besar dari tabel adalah 15,596 $>2,048$ dengan nilai signifikan (P value $=0,000<\alpha=0,05)$. Sedangkan Suku Bunga Bank Indonesia secara parsial tidak berpengaruh signifikan terhadap Pendapatan Margin Murabahah Perbankan Syariah di Indonesia. Hal ini ditunjukkan dari nilai $t_{\text {hitung }}$ lebih kecil dari $t_{\text {tabel }}$ adalah $-0,309$ $<2,048$ dengan nilai signifikan (P value $=0,759>\alpha=0,05)$.

2. Hasil pengujian secara silmutan menunjukkan nilai $F_{\text {hitung }}$ sebesar 127,326 sedangkan $F_{\text {tabel }}$ sebesar 3,354 dan nilai signifikan $\alpha=0,05$. Pendapatan signifikan $0,000<\alpha=0,05$, sehingga dapat disimpulkan bahwa Pembiayaan Murabahah dan Suku Bunga Bank Indonesia secara bersama-sama berpengaruh terhadap Pendapatan Margin Murabahah Perbankan Syariah di Indonesia.

\section{Saran}

Berdasarkan simpulan diatas maka ada beberapa saran untuk perusahaan/ bank dan bagi peneliti selanjutnya yang membahas dengan judul yang sama. Adapun saran tersebut adalah sebagai berikut:

1. Dalam penetapan persentasi pendapatan Margin Murabahah sebaiknya tidak lebih besar dari pada suku bunga Bank Indonesia yang ditetapkan oleh Bank Indonesia. Perbankan Syariah di Indonesia agar mengkaji kembali perhitungan Pendapatan Margin Murabahah, karena masih ada faktor-faktor lain yang mempengaruhi pendapatan margin murabahah, selain dari pembiayaan murabahah dan suku bunga Bank Indonesia.Perbankan syariah alangkah baiknya lebih selektif serta memperketat calon nasabah yang akan diberikan pembiayaan dan mempertegas dalam memberikan saksi kepada nasabah yang lalai, hal ini dilakukan untuk mengantisipasi terjadinya kelalaian dari nasabah sehingga akan berdampak pada pendapatan margin murabahah yang diterima.

2. Penelitian selanjutnya dapat juga dimasukkan variabel-variabel lain yang mempengaruhi Pendapatan Margin Murabahah perbankan syariah seperti unsur lainnya seperti faktor Bagi Hasil Dana Pihak Ketiga, Biaya Oprasional dan Faktor lain yang mempengaruhinya. 


\section{REFERENSI}

Achmad Solihin. 2010. MySQL 5 Dari Pemula Hingga Mahir. Jakarta: Universitas Budi Luhur.

Adiwarman Karim. 2008. Bank Islam: Analisis Fiqih Dan Keuangan Edisi Ketiga. Jakarta: Pt. Raja Grafindo Persada.

Adiwarman, Karim. 2011. Bank Islam “Analisis Fiqih Dan Keuangan”. Jakarta: PT. Raja Grafindo.

Binti Nur Asiyah. 2014. Manajemen Pembiayaan Bank Syariah. Yogyakarta: Teras.

Danang Sunyoto. 2013. Metode Penelitian Akuntansi. Cetakan kesatu. Bandung: PT. Refika Aditama.

Dwi Priyanto. 2012. Belajar Praktis Analisis Parametrik dan Non Parametrik dengan Statiscal Product and Service Solution (SPSS). Cetakan Pertama. Yogyakarta: Gava Media.

Ely, dkk. 2012. Pengaruh Suku Bunga Bank Indonesia Dan Pembiayaan Murabahah Terhadap Pendapatan Margin Murabahah (Studi Kasus Pada Bank Syariah Mandiri. Jurnal Akuntansi (Online).

Ismail. 2011. Perbankan Syariah. Cetakan Pertama. Jakarta: Prenada Media Group.

Kasmir. 2010. Manajemen Perbankan. Jakarta: Rajawali Pers.

Kasmir. 2013. Bank dan Lembaga Kuangan Lainnya. Edisi Revisi. Cetakan 12. Jakarta: Rajawali Pers.

Kenda Satya. 2013. Faktor-Faktor Yang Mempengaruhi Penetapan Margin Murabahah Pembiayaan Konsumtif Di Bank Kaltim Syariah. Jurnal Ekonomi Bisnis. (Online).

Lianana dan Lili Syafitri. 2012. Pengaruh Pembiayaan Murabahah Dan Tingkat Suku Bunga Bank Indonesia Terhadap Pendapatan Margin Murabahah Pada Pt Bank Mandiri Syariah. Jurnal akuntansi (Online).

Muhammad. 2007. Lembaga Ekonomi Syariah. Yogyakarta: Graha Ilmu.

Nur Indrianto dan Bambang Supomo. 2009. Metode Penelitian Bisnis. Yogyakarta : BPFE.

Pernyataan Standar Akuntansi Keuangan No.23 Tahun 2010 Tentang Pendapatan.

Sabiq Sayyid. 2008. Fiqih Sunnah. Jilid 5. Jakarta: Cakrawala Publishing.

Sri Nurhayati dan Wasilah, 2012. Akuntansi Syariah di Indonesia. Edisi 2 Revisi. Jakarta: Salemba Empat.

Sugiyono. 2014. Metode Penelitian Bisnis. Cetakan kelima belas. Bandung: Alfabet

Sunjoyo, dkk. 2013. Aplikasi SPSS untuk Smart Riset. Cetakan kesatu. Bandung: ALFABETA.

Syafi'i Antonio. 2005. Bank Syariah Dari Teori ke Prakti. Cetakan ke-9. Jakarta: Tazkia Cendekia.

Undang-Undang No. 21 Tahun 2008 Tentang Perbankan Syariah.

Warsono, dkk . 2011. Akuntansi Transaksi Syariah. Yogyakarta: Asgard Chapter.

Wiroso. 2011. Akuntansi Transaksi Syariah. Jakarta: Ikatan Akuntansi Indonesia (IAI).

www.adln.lib.unair.ac.id 